\title{
Eastern States Harness Clean Energy to Promote Air Quality
}

\author{
by James M. Ferguson and Debra A. Jacobson
}

Reprinted from the July-August 2007 issue of Conservation Update, an electronic newsletter published by the U.S. Department of Energy State Energy Program. (http://www.eere.energy.gov/state_energy_ program/update/)

\section{States' Green Energy Choices Help To Clean the Air}

States are including renewable energy and energy efficiency in their air quality programs. They are motivated by federal requirements to reduce pollution and by the potential to provide long-term sources of revenue to clean energy projects through emissions trading.

Many states will encounter opportunities to bolster provisions for renewable energy and energy efficiency when they revise their air quality programs in the coming years and if the scope of cap-andtrade programs expands to include other pollutants. This publication will present an overview of how states in the eastern region of the nation are meeting these opportunities.

$$
\begin{aligned}
& \text { States have an opportunity } \\
& \text { to include measures that } \\
& \text { promote renewable energy } \\
& \text { and energy efficiency every } \\
& \text { time they revise their state } \\
& \text { implementation plans for air } \\
& \text { quality. }
\end{aligned}
$$

States can use renewable energy and energy efficiency projects to improve air quality through emissions trading under cap-and-trade programs. To do so, states must assign emissions allowances - each of which represents the authorization to emit one ton of a criteria pollutant - to the owner of a renewable energy or energy efficiency project, who then retires the allowances. In this case, the total number of allowances is reduced and air quality improves.

Another option is for the owner of the allowances to sell them to a fossil fuel generator and use the revenues to finance renewable energy and energy efficiency projects. In this case, air quality does not improve immediately, but the additional incentives will spur the development of renewable energy and energy efficiency projects that will improve air quality over the long term.

To better understand why some state regulations reduce pollution and provide financing for renewable energy and energy efficiency, we'll take a look at how cap-and-trade air quality programs work.

\section{States Use Renewable Energy and Energy Efficiency Projects to Reduce Pollution}

States have to establish air pollution reduction programs if areas within a particular state violate the National Ambient Air Quality Standards for certain air pollutants. As of June 2007, the U.S. Environmental Protection Agency (EPA) has designated areas in 391 counties as nonattainment for the eight-hour ozone standard and 208 counties as nonattainment for fine particulate 

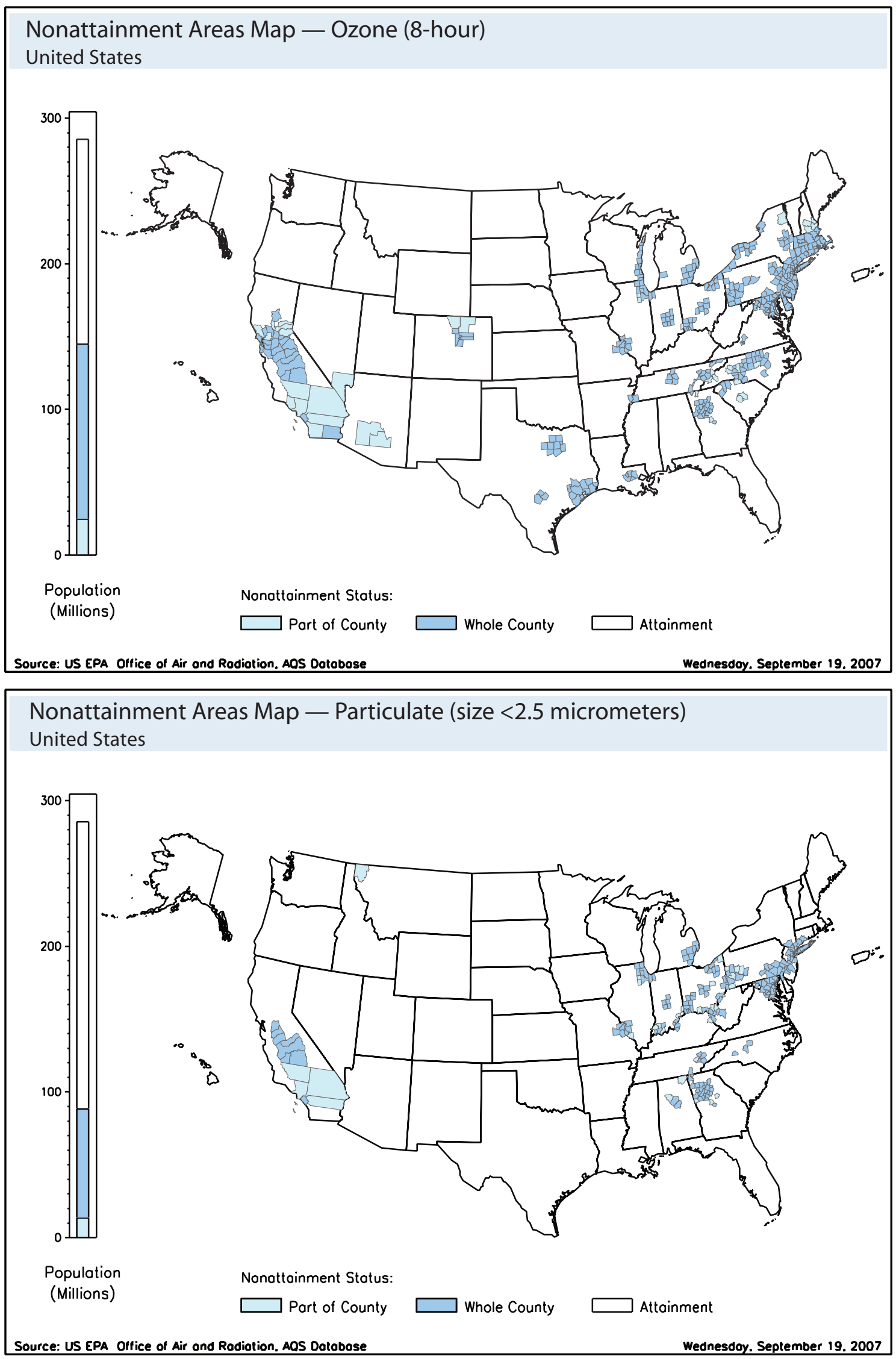

Most of the major population centers in the East, Midwest, California, and Texas lie in nonattainment areas for ozone, affecting 150 million people. Fine particulate matter affects 90 million people. Credit: U.S. Environmental Protection Agency 
matter (see maps on page 2). (The air quality standards, as well as other related information, are available on the EPA Web site, http://www.epa.gov.)

States with nonattainment areas are required to develop and submit to the EPA a state implementation plan (SIP) to reduce emissions of the specified pollutants. The EPA reviews the plan, which establishes a series of measures that are designed to achieve the required reductions.

Beginning three years ago, states began to include provisions for renewable energy in their SIPs. And in 2007, a number of states proposed energy efficiency measures in their SIPs for addressing the eight-hour ozone standard.

Currently, seven states - Indiana, Maryland, Massachusetts, Missouri, New Jersey, New York, and Ohio — have set-asides for renewable energy and energy efficiency projects that would allow project owners to retire allocations for nitrogen oxides $\left(\mathrm{NO}_{\mathrm{x}}\right)$ and allow the states to seek EPA approval for corresponding emission reductions.

\section{Clean Energy Programs Can Be Financed through Cap-and-Trade}

Cap-and-trade emissions programs that use market mechanisms to reduce emissions of criteria pollutants have been very successful in the United States. They help minimize the total costs of meeting emission reduction targets and have become the preferred method for reducing emissions among many members of the power industry.

Unfortunately, some emissions trading programs provide little or no value for energy efficiency and renewable energy technologies. For example, Congress specifically allocated all allowances for sulfur dioxide emissions to fossil fuel generators under Title IV of the Clean Air Act Amendments of 1990. Although the law includes a provision to benefit renewable energy, it proved ineffective. As a result, renewable energy and efficiency projects are excluded from receiving sulfur dioxide allowances.

The Clean Air Act allows much greater flexibility for providing incentives to renewable energy and energy efficiency projects in the $\mathrm{NO}_{\mathrm{x}}$ emissions trading program; this flexibility provides an opening for clean energy providers.

$\mathrm{NO}_{\mathrm{x}}$ pollution is a precursor to ground-level ozone and to fine particulate pollution. Read about the harmful effects of breathing ozone on the Ozone Transport Commission's About Ozone page at http://www.otcair.org/ozone.asp.

Most states with $\mathrm{NO}_{\mathrm{x}}$ cap-and-trade programs (except for those with set-asides) allocate all $\mathrm{NO}_{\mathrm{x}}$ allowances to fossil fuel generators. Nevertheless, the EPA does not require this approach. In fact, the EPA allows states to include renewable energy and energy efficiency in their SIPs to reduce $\mathrm{NO}_{\mathrm{x}}$ emissions. And since 2005, the EPA and the U.S. Department of Energy (DOE) have helped several East Coast states include renewable energy and energy efficiency in their SIP requirements through the DOE Clean Energy/Air Quality Integration Initiative.

Cap-and-trade programs can provide significant revenues for renewable energy and energy efficiency projects. In recent years, allowances for $\mathrm{NO}_{\mathrm{x}}$ emissions have been trading at $\$ 1,000$ to $\$ 3,000$ per ton. At these prices, developers of renewable energy and energy efficiency projects could expect to earn $\$ 0.74$ to $\$ 6.00$ per megawatt-hour from trading $\mathrm{NO}_{\mathrm{x}}$ emissions credits, depending on the technology and location.

\section{The Clean Air Interstate Rule Cracks Open the Door}

At first blush, air quality seems to be intrinsically linked with renewable energy and energy efficiency. Most renewable energy technologies, such as wind and solar energy, generate electricity with zero or very low emissions, and energy efficiency displaces the need for power generation.

\section{The Devil Is in the Details}

There are two ways to allocate $\mathrm{NO}_{\mathrm{x}}$ allowances for emissions trading that are favorable to renewable energy and energy efficiency projects: direct allocations and clean energy set-asides.

Of these two approaches, direct allocations of allowances to renewable energy and energy efficiency projects are the most favorable to project developers because they last for the life of the project or the air quality program. Investments in renewable energy and energy efficiency

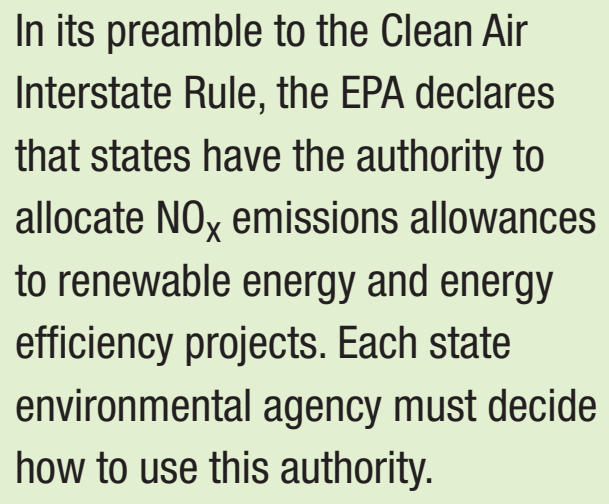




\section{States Covered by the Clean Air Interstate Rule}

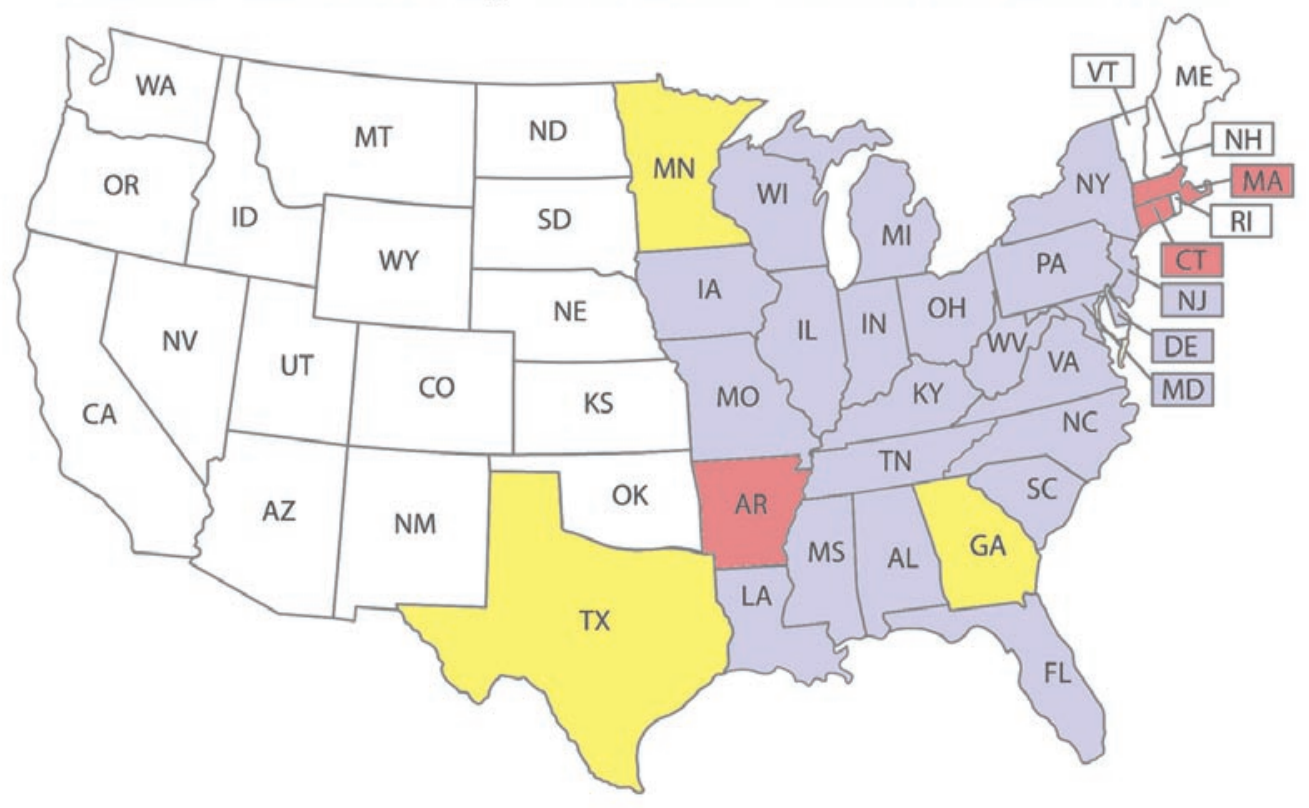

ozone and particles - AL, DE, FL, IL, IN, IA, KY, LA, MI, MS, MO, NJ, NY, NC, OH, PA, SC, TN, VA, WV, DC, WI

ozone only - $A R, C T, M A$

particles only - GA, MN, TX

not covered by CAIR

Credit: U.S. Environmental Protection Agency are capital intensive and almost always require long-term financing. The financial community will consider only stable, long-term public policies when setting the terms for project financing. Direct allocations better meet this longterm requirement than clean energy set-asides.

In April 2007, the Pennsylvania Environmental Quality Board proposed regulations that provide an example of a direct allocation of $\mathrm{NO}_{\mathrm{x}}$ allowances to renewable energy and energy efficiency projects. This direct allocation would place these projects on par with conventional generators in addressing air quality. The Pennsylvania regulations are expected to take effect in 2010.

Another type of approach to support clean energy projects under the Clean Air Interstate Rule is known as a clean energy set-aside. Under this approach, a state will set aside a certain percentage, usually $1 \%$ to $10 \%$ of its total allowances, for clean energy.

Currently, seven states have set-asides for renewable energy and energy efficiency under the EPA $\mathrm{NO}_{\mathrm{x}}$ SIP Call, which is the name of the current cap-and-trade program for $\mathrm{NO}_{\mathrm{x}}$. These emissions trading arrangements and the set-asides are scheduled to expire at the end of 2008 .

In 2009, the Clean Air Interstate Rule will replace the $\mathrm{NO}_{\mathrm{x}}$ SIP Call as the regulatory framework governing $\mathrm{NO}_{\mathrm{x}}$ emissions trading, and many new states have issued regulations with set-asides or direct allocations of $\mathrm{NO}_{\mathrm{x}}$ allowances to clean energy projects (see chart on page 5).

Set-asides have proven to be a step forward. Of the 20 states with $\mathrm{NO}_{\mathrm{x}}$ cap-and-trade programs, only seven currently allow renewable energy and energy efficiency project owners to retire emissions allowances. Although this set-aside approach is less favorable than direct allocation, it is far more favorable than the previous approach in most states that allocated all allowances to fossil fuel generators.

If small-scale energy efficiency projects and renewable generators such as solar energy are to be included, another issue must be addressed. It involves the size of the allocations. Typical allocations for emissions trading programs are measured in tons of $\mathrm{NO}_{\mathrm{x}}$, and until recently, the EPA has been unwilling to recognize transactions that involve fractions of tons. This practice places efficiency and solar projects at a disadvantage because each contributes small reductions in emissions - generally much less than one ton.

One answer is for states to allow aggregation of small projects that, taken together, can reach the one-ton threshold. Of the states with clean energy set-asides, only Massachusetts currently allows aggregation of small projects. It is thus the only state to use all its set-aside for renewable energy and energy efficiency. States such as Connecticut and Virginia can allow project aggregation beginning in 2009 according to new emissions trading rules issued under the new Clean Air Interstate Rule. 


\section{How Can Emissions Reductions Be Validated?}

States also need to document that their particular renewable energy and energy efficiency programs result in measurable emissions reductions. This documentation can be challenging, as it must match the constantly changing emissions profiles of online power plants as they ramp up and down to meet fluctuating daily demands. Similarly, the operating schedules of renewable energy and energy efficiency technologies depend on variable resources and user schedules.

How can this huge volume of data be reconciled? DOE outlines five methods in its first report on state air quality programs published in August 2006 titled, Final Report on the Clean Energy/Air Quality Integration Initiative Pilot Project of the U.S. Department of Energy's Mid-Atlantic Regional Office.

- System mix analysis uses the weighted average of emissions from all generators on the system. This is the simplest method and is applied by the widely used EPA e-Grid. In the real world of power plant dispatch, however, renewable generators and energy efficiency measures rarely displace large hydroelectric or nuclear generation. This method underestimates emissions reductions from renewable generators.

- Surrogate plant analysis calculates emissions displaced from the next unit that utilities plan to add to their system. In the East, this is usually a natural gas-fired plant with very low $\mathrm{NO}_{\mathrm{x}}$ emissions. This method also underestimates reductions from many renewable energy and efficiency projects.

\begin{tabular}{|c|c|c|c|c|}
\hline \multirow[b]{2}{*}{ State } & \multirow[b]{2}{*}{ Rule Status } & \multicolumn{2}{|c|}{ Set-Asides for RE \& EE } & \multirow{2}{*}{$\begin{array}{l}\text { Direct Allocation } \\
\text { Based on kWh of } \\
\text { generation }\end{array}$} \\
\hline & & $\begin{array}{l}\text { Summer Ozone } \\
\text { Season }\end{array}$ & Annual & \\
\hline Connecticut & Final Draft & $10 \%$ & - & \\
\hline District of Columbia & Internal Deliberations & $5 \%$ (expected) & $5 \%$ (expected) & \\
\hline Illinois & Proposed & $12 \%$ (RE \& EE) & $12 \%$ (RE \& EE) & \\
\hline Indiana & Final & $2.43 \%$ & $0.5 \%$ & \\
\hline Massachusetts & Final & $10 \%$ & - & \\
\hline Maryland & Proposed & $5 \%$ * & $5 \%$ * & \\
\hline Michigan & Final & $0.7 \%$ (RE) & - & \\
\hline Missouri & Proposed & - & $0.5 \%$ & \\
\hline New Jersey & Proposed & $5 \%$ & $5 \%$ & \\
\hline New York & Proposed & $10 \%$ & $10 \%$ & \\
\hline Ohio & Proposed & $1 \%$ & - & \\
\hline Pennsylvania & Proposed & & & $x$ \\
\hline Virginia & Final & $1 \%$ with banking & $1 \%$ with banking & \\
\hline Wisconsin & Proposed & & & $x$ \\
\hline
\end{tabular}

* Some states' rules support renewable energy and energy efficiency projects with set-asides for and direct allocations to clean energy under the Clean Air Interstate Rule better than others. For example, banking in Virginia allows those holding the allowances to carry them over into the next year, which allows greater flexibility for their use. Maryland mixes its set-aside for clean energy with new fossil generation, so the pool is potentially much diminished for renewable energy generators under that scenario. The percentages refer to the fraction of NOx allocations given to all generators. Credit: DJ Consulting LLC 
- Generation-weighted average of fossil fuel units takes into account only fossil fuel units that are used to follow loads on a particular grid for estimating emissions.

DOE used this method to estimate emissions in its August 2006 report for the Mid-Atlantic Region.

- Time-matched and generation-weighted average of fossil fuel units that are used to follow load is a refinement of the previous method that matches hour-by-hour output of renewable generators or the load profile of energysaving measures with the load profile of fossil fuel units in a particular power marketing area. This method is more complex than the generation-weightedaverage approach and presents hurdles for programs for which hour-by-hour operating schedules are not available. (Usually, time-matched emissions data are available from the EPA in the form of output from continuous emissions monitors.) The Metropolitan Washington Air Quality Committee used this method to estimate emissions reductions from light-emitting diode (LED) traffic signal retrofits.

- Complete grid-system dispatch analysis takes a utility-scale approach to the entire grid. It takes into account the dispatch schedules of power generators in addition to the output schedules of renewable generators. This is an expensive analysis that sometimes depends on using proprietary information that belongs to utility companies and power system operators.

In February 2004, Maryland used this method in its 2004 SIP to meet the onehour ozone standard to justify a Montgomery County-led regional purchase of wind energy. The purchase was for 5\% of the buying group's electricity consumption, about 38.4 million kilowatt-hours $(\mathrm{kWh})$ per year. It was the largest municipal purchase of wind energy at the time. The following year, the EPA approved the Maryland wind purchase as the first-ever renewable energy purchase in a SIP. You can read about the Montgomery County wind energy purchase in a DOE Wind Powering America fact sheet titled, "Improving Regional Air Quality with Wind Energy."

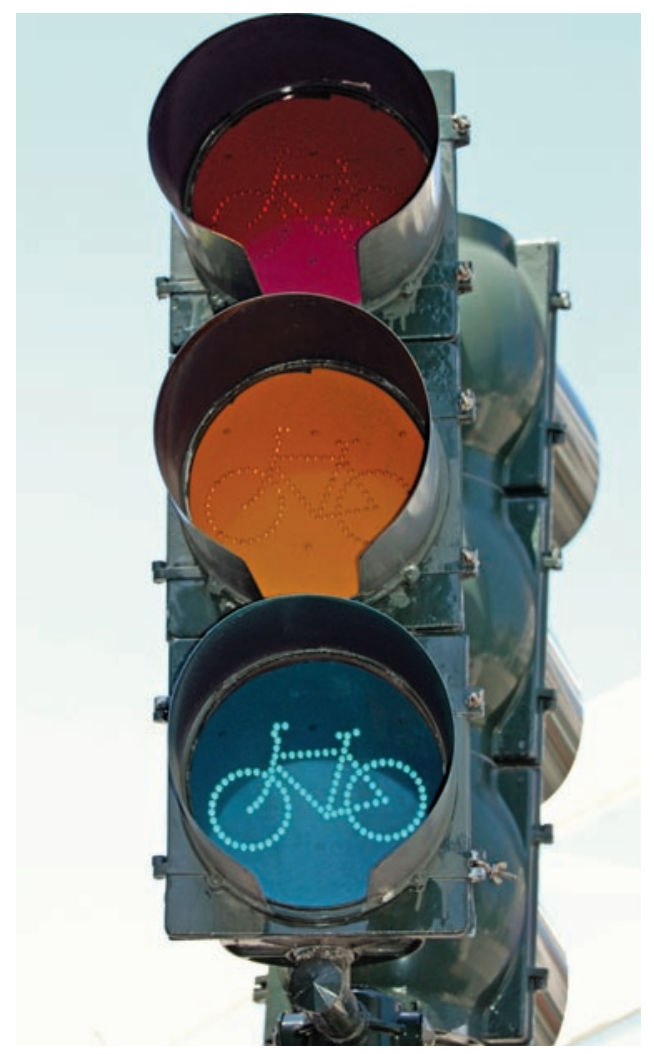

The regional air quality plan submitted to the EPA in March 2007 by Maryland, Virginia, and the District of Columbia was the first such plan to include LED traffic signals as a pollution control measure. Credit: iStockphoto\#3410790

The EPA publishes a complete list of data handling and analysis options for states in a report it published in April 2006 titled, Clean-Energy-Environment Guide to Action: Policies, Best Practices, and Action Steps for States.

\section{More Opportunities in 2008}

The Clean Air Interstate Rule issued by the EPA in 2005 provides more opportunities for states to support their renewable energy and energy efficiency programs because it requires states to modify their current rules for $\mathrm{NO}_{\mathrm{x}}$ emissions trading. This rule applies to 28 states in the East, South, and Midwest, and to the District of Columbia (see map on page 4). In this rule, the EPA specifically declares that states have the authority to allocate $\mathrm{NO}_{\mathrm{x}}$ emissions allowances to fossil fuel generators and to renewable energy and energy efficiency projects.

The Clean Air Interstate Rule enables states to design their air quality programs to promote the growth of renewable energy and energy efficiency technologies. States submitted SIPs for the $\mathrm{NO}_{\mathrm{x}}$ eight-hour standard earlier this year, and they will submit plans for reducing fine particulate matter (PM-2.5) in 2008. The caps for $\mathrm{NO}_{\mathrm{x}}$ emissions under the rule will take effect in 2009 and tighten in subsequent years. Each state implementation plan provides states an opportunity to include measures that promote renewable energy and energy efficiency.

\section{Metro Washington Coordinates Multi-State Wind Purchase, Efficiency}

Several states have already used the $\mathrm{NO}_{\mathrm{x}}$ emissions trading programs to launch innovative projects, including two multi-state air quality efforts that have a great potential for market transformation. And for the first time, states are using their air quality programs to aggregate efficiency measures, including energy-efficient traffic signals. 


\section{Aggregating Municipal Purchases of Renewable Energy Certificates}

In March 2007, the Metropolitan Washington Air Quality Committee completed a regional air quality plan for the eight-hour ozone standard for the District of Columbia - Maryland - Virginia Nonattainment Area. This plan built on the precedentsetting wind energy purchase in 2004 by a buying group led by Montgomery County, Maryland. In 2005, the EPA approved the wind purchase in the Maryland SIP, which became the first renewable energy purchase in the country to receive an emissions reduction credit in a state air quality plan.

The 2007 regional air quality plan increases municipal purchases of wind energy fourfold from 2004 to 2009. The buyers, including two counties in Maryland, three counties in Virginia, and the Washington Suburban Sanitary Commission, committed to purchase 123 million $\mathrm{kWh}$ of renewable energy certificates for wind energy annually.

Virginia, Maryland, and the District of Columbia also are installing thousands of traffic signals that use LEDs in place of conventional incandescent lights. This is the first time that LED traffic signals have been used as a pollution control measure in state air quality plans.

LED traffic signals use only $10 \%$ of the energy that conventional lights use and display brighter. They also burn out gradually when they need replacing. The combination of increased safety and lower costs from reduced energy consumption has made them very popular with transportation agencies.

\section{Eastern Seaboard States Reduce Emissions on Days When Demand for Electricity Is Highest}

The Ozone Transport Commission is leading a group of 12 states and the District of Columbia on the Eastern Seaboard in an effort to reduce $\mathrm{NO}_{\mathrm{x}}$ emissions on days when demand for electricity is high. Through this project, state environmental commissioners are discovering that utility-administered energy efficiency programs can achieve significant and cost-effective reductions in $\mathrm{NO}_{\mathrm{x}}$ that conventional cap-and-trade programs cannot achieve.

\section{Small Generators with High $\mathrm{NO}_{\mathrm{x}}$ Emissions}

The commission looked at $\mathrm{NO}_{\mathrm{x}}$ emissions on the days in the year with the highest demand for electricity. Utilities call these peak-demand days. On the East Coast, these are also the hottest days of the year when many people operate their air conditioners.

On the peak-demand days, utility dispatchers call for as much output as possible As a result of this work, six eastern states have made major commitments to energy efficiency beginning as soon as the 2009 ozone season. from all the power plants connected to the system. And they call on the demandreduction agreements they have with their customers. These utility demand-reduction programs consist of on-site generation and of conservation measures carried out by customers who participate in the programs.

Unfortunately, the power plants that utilities hold in reserve for peak demand days usually have the highest emissions. On-site generation by industrial - and some commercial - customers usually involves diesel-powered generators, which generally have high emissions. Furthermore, on-site generators used for backup power do not participate in emissions reductions programs. The result is that these high electricity demand days also have the highest $\mathrm{NO}_{\mathrm{x}}$ emissions.

By their nature, $\mathrm{NO}_{\mathrm{x}}$ cap-and-trade programs operate on a seasonal and an annual basis, and therefore cannot address emissions on specific days. The Connecticut Department of Environmental Protection (DEP), a member of the Ozone Transport Commission, wanted to know if the energy efficiency programs managed by the Connecticut Light and Power Company and the United Illuminating Company could reduce electricity consumption and $\mathrm{NO}_{\mathrm{x}}$ emissions on high electricity demand days in Connecticut.

\section{Much Work Remains To Be Done}

The DOE Clean Energy/Air Quality Integration Initiative provided support to the Connecticut DEP to calculate the potential electricity savings of the utility-administered energy efficiency programs. The analysts found that current programs enabled significant energy savings on peak-demand days. About two-thirds of the savings were achieved through lighting and airconditioning measures in homes, businesses, and industry. 
The analysts also concluded that the utility-administered efficiency programs could improve their data-gathering protocols to more readily calculate estimates of energy savings and emissions reductions. This is because most energy efficiency programs collect energy savings data on a gross level; more specific data are required to calculate emission reductions. The conclusion: energy efficiency offers a highly effective strategy for emissions reductions on high electricity demand days.

In March, the state members of the Ozone Transport Commission approved a Memorandum of Understanding (MOU) concerning the "Incorporation of High Electric Demand Day Emission Reduction Strategies into Ozone Attainment State Implementation Planning.”

In this document, the states agreed to use mechanisms that include energy efficiency programs to reduce 135 tons per day of $\mathrm{NO}_{\mathrm{x}}$ reductions on high electricity demand days. This $\mathrm{MOU}$ is a significant step because it involves a major commitment to energy efficiency from six states beginning as soon as the 2009 ozone season.

But the work has just begun. States are using various approaches to include renewable energy and energy efficiency in their air quality programs. With the help of the EPA and DOE, they are learning about what is required and how to make these programs pay off. And if future programs for greenhouse emissions trading are well designed, they too can spur new investment in renewable energy and energy efficiency.

\section{About the Authors}

James M. Ferguson serves as a senior management and energy adviser at the DOE National Energy Technology Laboratory (NETL) in Pittsburgh, Pennsylvania. Debra A. Jacobson is a professorial lecturer in energy law at The George Washington University Law School and the owner and principal of DJ Consulting LLC, which specializes in energy and environmental issues.

Neither the United States government nor any agency thereof, nor any of their employees, makes any warranty, express or implied, or assumes any legal liability or responsibility for the accuracy, completeness, or usefulness of any information, apparatus, product, or process disclosed, or represents that its use would not infringe privately owned rights. Reference herein to any specific commercial product, process, or service by trade name, trademark, manufacturer, or otherwise does not necessarily constitute or imply its endorse $\neg$ ment, recommendation, or favoring by the United States government or any agency thereof. The views and opinions of the authors expressed herein do not necessarily state or reflect those of the United States government or any agency thereof.

\section{Additional Information}

Program Assistance

James M. Ferguson

National Energy Technology Laboratory (NETL) James.Ferguson@netl.doe.gov

412-386-6043

DOE/GO-102007-2500 • October 2007
A Strong Energy Portfolio for a Strong America

Energy efficiency and clean, renewable energy will mean a stronger economy, a cleaner environment, and greater energy independence for America. Working with a wide array of state, community, industry, and university partners, the U.S. Department of Energy's Office of Energy Efficiency and Renewable Energy invests in a diverse portfolio of energy technologies. Energy by the National Renewable Energy Laboratory, a DOE national laboratory. Printed with a renewable-source ink on paper containing at least $50 \%$ wastepaper, including $20 \%$ postconsumer waste.
For more information contact: EERE Information Center 1-877-EERE-INF $(1-877-337-3463)$ www.eere.energy.gov 